\title{
O CORPO MONSTRUOSO NA HETEROTOPIA DA WEB
}

\author{
Dayane Oliveira ${ }^{1}$
}

\begin{abstract}
RESUMO: Por seu modo de funcionamento específico, a web se torna um espaço propício não apenas para se fazer ver, mas também para se fazer ver o outro. É nesse cenário onde se encontram os corpos monstruosos, objeto deste artigo, os "presos" que ficaram famosos na internet, por meio da plataforma YouTube. Nossos objetivos são: investigar como o corpo monstruoso é espetacularizado no espaço heterotópico da web; e analisar os conflitos morais e éticos que são provocados pelo processo de hipervisibilidade desses sujeitos criminosos no YouTube. Para alcançarmos tais objetivos, buscamos suporte nos estudos de Michel Foucault sobre sujeito e poder, dentro das suas contribuições para a Análise do Discurso, mobilizando discussões acerca das relações de saber/poder que constituem os sujeitos, bem como reflexões sobre verdade, moralidade e corpo na sociedade ocidental. Dentro de uma dispersão, selecionamos, por sua singularidade, o vídeo "Morre diabo - Mata a mãe e xinga imprensa". Esse acontecimento reverberou na Web de diversas formas (memes, remixes, performances etc.), dentre as quais optamos pelo gênero comentário. Foi possível, assim, verificar uma mutabilidade da identidade do sujeito criminoso na web, o que produz discussões importantes acerca da moral e da ética dos participantes da cibercultura e, consequentemente, da sociedade como um todo.
\end{abstract}

PALAVRAS-CHAVE: Análise do Discurso. Corpo Monstruoso. Sujeito. Identidade.

ABSTRACT: The web becomes, through its specific way of functioning, a space that is conducive not only to make itself seen, but also to make the other seen. It is in this scenario where the monstrous bodies are found, object of this work, the "prisoners" who became famous on the internet through the YouTube platform. Our goals are to: investigate how the monstrous body is spectacularized in the heterotopic web space: and analyze the moral and ethical conflicts that are triggered by analyzing the hypervisibility process of infamous criminal subjects on YouTube. To achieve these goals, we seek support in Michel Foucault's studies on subject and power, within his contributions to Discourse Analysis, mobilizing discussions of the knowledge / power relations that constitute the subjects, as well as reflections on truth, morality and body in western society. Within a dispersion, we selected, for its uniqueness, the video "Dies Devil - Kills Mother and Curses Press". This event reverberated on the web in various forms (memes, remixes, performances), from which we opted for the comment mode. Thus, it was possible to verify a mutability of the identity of these criminal subjects on the web, which produces important discussions about the morals and ethics of cyberculture participants and, consequently, of society as a whole.

KEYWORDS: Discourse Analysis. Monster body. Subject. Identity.

\section{Introdução}

\footnotetext{
${ }^{1}$ Doutoranda do curso de Pós-graduação em Linguística (PROLING) da Universidade Federal da Paraíba (UFPB), João Pessoa - Paraíba, Brasil. E-mail: dayane.ato@gmail.com
} 
PERcursos Linguísticos • Vitória (ES) •v. 10 •n. 25 • 2020 • ISSN: 2236-2592 • Dossiê:

Discursos de resistência e corpos (re)existentes

O monstro cessou de ensinar uma norma que doravante o inclui. O "poder de normalização" mudou de natureza: a normalização do anormal sucedeu à exibição. Mas uma questão permanece: quem assume hoje a função, outrora reservada às monstruosidades humanas, de fazer a demonstração do anormal? Quem são os novos monstros, estes "monstros pálidos" da anomalia cujo advento Michel Foucault predizia?

(Jean Jaques Courtine)

Na obra Decifrar o corpo: pensar com Foucault (2013), Jean Jacques Courtine utiliza o método arquegenealógico para abordar a história das curiosidades sobre os corpos anormais e monstruosos no século XVIII, esquadrinhando a "glória efêmera dos fenômenos da feira", seus dispositivos, suas encenações, seus discursos, seus públicos. Ancoramo-nos nessa investigação histórica das práticas de exposição/exploração do corpo teratológico para pensar o corpus deste artigo, pois acreditamos que essa cultura não cessou, apenas tomou outras formas e se adequou às tecnologias do nosso tempo. Por isso, objetivamos responder, em certa medida, ao questionamento feito por Courtine na epígrafe que dá início a esta introdução: Quem são os novos monstros e onde eles aparecem?

No século XVIII, as monstruosidades humanas saíram aos poucos do universo do assombro, da maldição e do milagre, da manifestação do divino e do diabólico para o lugar do entretenimento, atendendo a uma demanda aguda por diversão nas grandes cidades, resultado do processo de urbanização que ocorria em toda a Europa. De acordo com Courtine (2013), a história desses corpos era marcada no nascimento como prodígio ou pecado e, posteriormente, eram destinados a passar a infância e a vida adulta divertindo o público nas praças e nas feiras até serem confiscados pela Medicina, por ocasião de suas mortes.

O referido autor buscou elaborar uma arqueologia da curiosidade, isto é, das formas como as deformidades humanas se constituíam a partir do olhar furtivo e curioso das multidões, no qual os "erros e transgressões da natureza" eram docilizados e domesticados para despertar a simpatia da multidão:

Surpreendei-nos: mostrai-nos os prodígios, as maravilhas, os erros e as transgressões das leis da natureza. Mas assegurai-nos: mostrai-nos gnomos que sejam dóceis pequenos homens, grotescas harmoniosas, doces e inofensivas, seres mutilados que recuperam seu poder perdido; fazei-nos adivinhar os restos de humanidade perdidos sob o pelo da fera. (COURTINE, 2013, p. 111). 
Sendo assim, não é qualquer corpo que pode fazer parte do espetáculo das anormalidades, é preciso que seja disciplinado e, mesmo em sua forma monstruosa, não apresente perigo à população. Observando a exigência daquele público por corpos dóceis, pensamos, hoje, no corpo monstruoso que constitui o corpus desta pesquisa, considerando que ele também faz parte de um espetáculo, mas, agora, no espaço virtual.

Por seu modo de funcionamento específico e singular, a web torna-se um espaço propício não apenas para se fazer ver, mas também para se fazer ver o outro. No espaço virtual, se encontra todo tipo de anormalidade, bizarrice, perversão e violência, substituindo os mercados, feiras e circos dos séculos passados, sem perder, no entanto, a prática do exercício da curiosidade e a cultura da diversão. É nesse cenário onde se encontra o corpo monstruoso, objeto desta investigação, o qual compõe um arquivo de sujeitos criminosos que ficaram famosos na web.

Emílio Rocha, 33 anos, usuário de drogas, com um histórico de problemas mentais, mata a mãe a facadas e viraliza na internet ao ter sua entrevista (concedida ao programa televisivo Boa Tarde Paraná) compartilhada e divulgada na plataforma YouTube com o nome "Morre diabo - Mata a mãe e xinga imprensa”. Esse acontecimento nos chama atenção, não apenas pela brutalidade, mas pela forma como reverberou na web, através da apropriação do discurso do assassino pelos internautas, o que o transformou em $m e m e^{2}$, ressignificando-o. Esse acontecimento singular faz parte de uma série de vídeos do mesmo tema, são os "presos engraçados da internet", o que nos faz questionar: como crimes brutais se tornam piadas na internet?

Propomo-nos, pois, a investigar como o corpo monstruoso é espetacularizado no espaço heterotópico da web e se torna um objeto de entretenimento e diversão, analisando os conflitos morais e éticos que são provocados a partir do processo de hipervisibilidade do sujeito criminoso Emilio Rocha, no YouTube.

Para alcançarmos tais objetivos, buscamos suporte nos estudos de Michel Foucault sobre sujeito e poder, a partir de suas contribuições para a Análise do Discurso, mobilizando discussões acerca das relações de saber/poder que constituem os sujeitos, bem com reflexões sobre verdade e moralidade na sociedade ocidental.

Para a constituição do corpus, consideramos o princípio discursivo da dispersão, proposto por Foucault (2016), no qual o discurso se caracteriza pela coexistência de enunciados

\footnotetext{
${ }^{2}$ Derivado da palavra mimeme, que significa àquilo que pode ser imitado, o conceito de meme foi criado por Richard Dawkins (2007) que faz uma proximidade fonética com a ideia de "gene", construindo a metáfora de que a repetição faz parte do DNA da cibercultura.
} 
PERcursos Linguísticos • Vitória (ES) •v. 10 •n. 25 • 2020 • ISSN: 2236-2592 • Dossiê:

Discursos de resistência e corpos (re)existentes

dispersos e heterogêneos. Seguindo esse princípio, a montagem do corpus envolve diversos enunciados, que aparecem em lugares distintos, mas se referem ao mesmo tema ou acontecimento. Quando tratamos do corpus em sua dispersão, estamos considerando-o no espaço descontínuo do arquivo do qual ele faz parte e que, neste trabalho, diz respeito aos "presos engraçados da internet". Dentro dessa dispersão, selecionamos, por sua singularidade, o caso de Emilio Rocha (narrado anteriomente nesta seção), pois é o único caso de assassinato dentro do arquivo investigado. Encontramos ainda esse acontecimento reverberado na forma de comentários, memes, remixes, performances/interpretações. No entanto, seria exaustivo reunir e analisar todo o material encontrado. Optamos, assim, por nos aprofundar em apenas uma das dessas modalidades, o comentário.

O que nos propomos neste artigo é pensar sobre um fenômeno digital que não é novo, afinal, a violência, o bizarro e a loucura sempre foram na sociedade ocidental, em diferentes épocas, formas de entretenimento. Ridicularizar o estranho, o anormal, o corpo deformado ou supliciar o criminoso são práticas históricas. No entanto, trata-se agora de analisar como isso acontece no nosso tempo. É importante entendermos como a web se constitui como esse lugar em que os limiares da ética e da moral são contraditoriamente firmes e turvos, pois acreditamos que isso, de alguma maneira, afeta os alicerces não tão sólidos da nossa sociedade.

\section{O corpo monstruoso na obra foucaultiana}

Para entendermos o funcionamento da forma contemporânea de espetacularização do corpo monstruoso, é preciso evocar a noção de monstro na perspectiva foucaultiana, que apesar de se aproximar do anormal, possui características diferentes. Como afirma o próprio Courtine (2013, p. 84), Foucault vai pensar os corpos monstruosos através da história da constituição do olhar biológico, médico, da genealogia dos dispositivos de identificação e vigilância dos corpos criminosos, e do questionamento dos poderes de normalização. Sob essa ótica, para Foucault (2010), o corpo monstruoso é definido por uma tríade, formada pela Biologia, pela Medicina e pelo Direito, sendo assim "contranatural" e "fora da lei".

O contexto de referência do monstro humano é a lei, é claro. A noção de monstro é essencialmente uma noção jurídica - jurídica, claro, no sentido lato do termo, pois o que defini o monstro é o fato de que ele constitui em sua existência mesma e em sua forma, não apenas uma violação das leis da sociedade, mas uma violação das leis da natureza. Ele é, num registro duplo, infração às leis em sua existência mesma. $\mathrm{O}$ campo de aparecimento do monstro é, portanto, um domínio que podemos dizer ‘jurídico-biológico'. (FOUCAULT, 2010, p. 47) 
PERcursos Linguísticos • Vitória (ES) •v. 10 •n. 25 • 2020 • ISSN: 2236-2592 • Dossiê:

Discursos de resistência e corpos (re)existentes

O anormal, sob a ótica foucaultiana, está para as ciências da natureza e da lei sob a forma de três figuras elementares: o monstro, o incorrigível e o onanista. O "monstro humano", como denomina Foucault, pode ser definido como jurídico-biológico, pois a sua existência é uma violação, não apenas da lei dos homens, mas da própria natureza. O “indivíduo a ser corrigido”, por sua vez, é um fenômeno do cotidiano, sobre o qual se aplicam tecnologias de reeducação e correção por parte de diferentes instâncias sociais, como família, escola, igreja, polícia etc. O onanista é o "masturbador" (ou ainda a criança masturbadora), que aparece no espaço familiar, sobre o qual as interdições recaem diretamente sobre o corpo e a sexualidade. Assim, para Foucault (2010), o indivíduo anormal do século XIX é marcado - na prática médica, na prática jurídica, na prática sexual, dentro das instituições que vão rodeá-lo - por uma espécie de monstruosidade, que se tornou cada vez mais apagada e diáfana por aparelhos de retificação e projetos disciplinares de normalização.

Segundo Courtine (2013), nas últimas décadas do século XIX, teve início um processo lento no qual a exploração econômica das deformidades humanas começou a perder força até desaparecer completamente ao longo do século XX. O sentimento de compaixão e um olhar mais humanizado sobre o corpo monstruoso tornou a curiosidade e a admiração do público das feiras em uma prática doentia e indecente. De acordo com o autor, esse processo ocorreu por diversos fatores: a divisão social crescente dos públicos, a canalização progressiva da curiosidade popular, a administração moral e racional do olhar, e a tomada definitiva do corpo monstruoso pela ciência.

O monstro natural cede então espaço para a monstruosidade moral ou criminal, cujos efeitos estão no campo da conduta e não mais da natureza: "vemos emergir uma espécie de domínio específico, que será o da criminalidade monstruosa ou da monstruosidade que tem seu ponto de efeito não na natureza e na desordem das espécies, mas no próprio comportamento" (FOUCAULT, 2010, p. 63). Nesse processo, surge o dispositivo da punição, que no Direito clássico apresentava um desequilíbrio em torno dos rituais de atrocidade, pois envolvia os castigos. Desse modo, o poder soberano era sempre maior e mais feroz do que qualquer crime, podendo, assim, absolvê-lo. Isso resultou, como aponta Foucault em Vigiar e punir (1987), nas grandes cenas de suplício. Mas, a partir do século XVIII, em virtude do aprimoramento de tecnologias científicas e da emergência da Revolução Industrial, além de um refinamento de certas formas políticas de governo, surge a necessidade de se investigar a natureza do criminoso. Nascia nesse século "uma nova economia dos mecanismos de poder" que permitiam majorálo: 
O século XVIII encontrou certo número de meios ou, em todo caso, encontrou o princípio segundo o qual o poder - em vez de se exercer de uma maneira ritual, cerimonial, descontínua, como era o caso tanto do poder do feudalismo como ainda da grande monarquia absoluta - tornou-se contínuo. [...] Em vez de ter por objeto pontos, gamas, indivíduos, grupos arbitrariamente definidos, o século XVIII encontrou mecanismos de poder que podiam se exercer sem lacunas e penetrar o corpo social em sua totalidade. (FOUCAULT, 2010, p. 74).

Assim, os efeitos do poder poderiam ser sentidos por todo o corpo social, de forma totalitária e absoluta, como "uma espécie de lei” necessária, que se faz ser obedecida através de mecanismos permanentes de vigilância e controle. Essa é a base da sociedade disciplinar, na qual o exercício do poder se integra aos mecanismos de produção, reduzindo seus custos e cultivando, assim, corpos produtivos e dóceis. Dessa forma, de acordo com Foucault (2010), essa nova economia do poder não apenas reduz as despesas de seu exercício, como também diminui as possibilidades de resistência e descontentamento que o poder feudal e monárquico suscitava.

Temos, portanto, nesse novo conjunto tecnológico do poder, três características importantes, destacadas por Foucault (2010): (I) o poder de punir associado à vigilância; (II) a correspondência direta entre crime e pena; e (III) a punição na medida, sem excessos. Essa última, por sua vez, é avaliada a partir da razão do crime, é o que leva, por exemplo, à associação entre os saberes médicos e legislativos (psiquiatria penal), os quais proporcionam a aparição do louco criminoso, por exemplo. Essa perspectiva de poder é a base da sociedade disciplinar e da biopolítica, que, por sua vez, são os eixos que conformam o biopoder. Assim, a normalização refere-se a esse processo de regulação da vida, dos corpos, dos indivíduos e da população.

No olhar foucaultiano, é na relação entre o saber e o poder que agem os dispositivos de normalização do sujeito. Primeiro isolam e depois distinguem os anormais, aqueles que estão fora da norma. É nisso que consiste, portanto, o poder de normalização, enquanto estratégia dominante, pois é na exibição do corpo anormal que "o monstro continua sendo uma exceção que confirma uma regra" (COURTINE, 2013, p. 126).

Pensando no objeto deste trabalho, podemos dizer, portanto, que Emílio Rocha, o sujeito que protagonizou o vídeo intitulado Morre Diabo - mata a mãe e xinga a imprensa, se constitui como esse monstro foucaultiano, cuja anormalidade está no comportamento. Sua monstruosidade se explica pela gravidade do crime, pois ele assassinou a própria mãe a facadas. Trata-se, portanto, do monstro moral, cujo ponto de desequilíbrio não está mais na natureza, mas sim no comportamento. No entanto, diferente de Foucault, não nos interessa aqui observar o sujeito criminoso na prisão, mas sim em um espaço diferente, no qual os dispositivos de vigilância e punição não operam, pelo contrário, escapam. Nesse lugar, os monstros da nossa 
PERcursos Linguísticos • Vitória (ES) •v. 10 •n. 25 • 2020 • ISSN: 2236-2592 • Dossiê:

Discursos de resistência e corpos (re)existentes

sociedade se tornam entretenimento e diversão, é a feira das anormalidades no século XXI, em sua forma mais dinâmica.

\section{O monstro que faz rir}

Produto de uma reportagem veiculada pela filial da Rede Bandeirantes de televisão no Paraná, o vídeo, intitulado Morre Diabo - mata a mãe e xinga a imprensa, foi publicado pela primeira vez no YouTube no dia 19 de novembro de 2010 pelo canal Lucas Vaz Fido. Emílio Rocha, 33 anos, usuário de crack e cocaína, com um histórico de problemas mentais, mata a mãe na cozinha de casa a facadas, no dia 19 de setembro de 2010. Ao ser preso, foi abordado por jornalistas ainda na delegacia, entre eles estava Bruno Henrique do programa Boa tarde Paraná, onde a reportagem foi exibida. Emilio se recusou a falar e insultou todos os jornalistas que tentavam realizar a entrevista. Abaixo, a transcrição do vídeo:

Transcrição do vídeo:

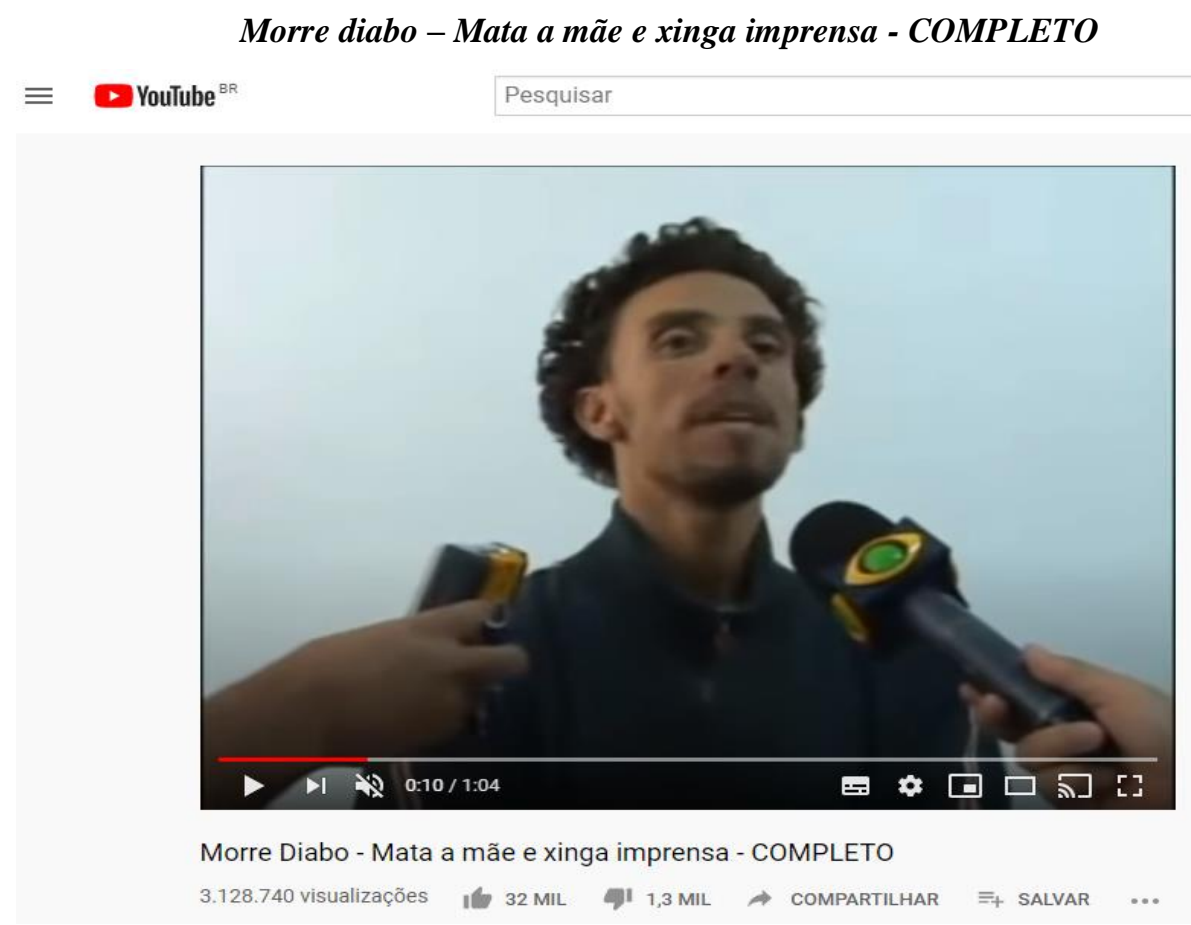

Fonte: YouTube.

Emílio Rocha: Meu único direito é ficar calado, não quero falar com bandeirantes, com ninguém na frente das câmeras, tá bom?

Bruno Henrique: Por que que você matou sua mãe, rapaz?

Emilio Rocha: Não interessa pra você, palhaço! Falô, maluco?! Eu gosto da câmera, o microfone pra mim é tudo! Mas pra você... Eu não quero falar com você! Ah, morre diabo!

Outro jornalista: Fala aqui pra gente então...

Emílio Rocha: Tô falando, num tô falando?! Então morre, diabo! 
PERcursos Linguísticos • Vitória (ES) •v. 10 •n. 25 • 2020 • ISSN: 2236-2592 • Dossiê:

Discursos de resistência e corpos (re)existentes

Outro jornalista: $O$ que que aconteceu lá, ein? Ela estava usando seus cartões de crédito?

Emilio Rocha: Não interessa, não interessa! Isso é problema meu! Eu quero que você se foda, seu filho duma puta! Tá me ouvindo? É pra gravar? Gravou então! Vocês se foda!

Observamos que o sujeito detido manifesta seu direito de permanecer calado, recusando-se a dar entrevistas, mas, a partir da insistência do repórter, ele inicia uma série de insultos contra a imprensa. Entendemos que esta é uma prática comum ao trabalho jornalístico, é preciso fazer falar, por isso, mesmo após receber o primeiro insulto, os repórteres insistem, até Emilio ser levado pelos policiais.

É importante destacar que, para Emilio Rocha, essa visibilidade só foi possível a partir do encontro com o poder, que se deu pela transgressão da lei. Podemos observar a atuação do dispositivo jurídico com técnicas específicas (e amplas) de atuação através das leis, da polícia e de organizações arquitetônicas como a delegacia e a prisão, que subjetivam esse sujeito enquanto homicida, criminoso. Por outro lado, vemos também a atuação da mídia, que expõe esse sujeito, o torna visível, tirando-o da infâmia, apresentando-o "do ponto de vista em que ele deve ser visto e, esse ponto, por si mesmo, já é disciplinar: a educação da visão pela determinação do visível" (GOMES, 2003, p. 75).

Nessa perspectiva, a mídia funciona como um dispositivo disciplinar, pois ela (des)constrói verdades e monta cenários, ainda que metaforicamente, para que possamos viver e agir em conformidade com aquilo que nos é colocado. No entanto, é na web que o sujeito ganha hipervisibilidade e encontra um espaço propício para promover novas formas de subjetivação. É a convergência entre as mídias televisiva e digital que potencializa essa exposição do sujeito infame, alcançando um número muito maior de "espectadores" ( mais de três milhões), o que não seria possível apenas com uma única transmissão televisiva.

É importante fazermos uma análise da fisionomia do sujeito, pois quando se trata do estudo de uma materialidade audiovisual, o corpo e o rosto também falam e significam. De acordo com Courtine e Haroche (2007), em diferentes escritos científicos de ordens e origens diversas, procurou-se estabelecer a ligação da parte externa do corpo às qualidades morais da alma; entender o interno, abstrato e psicológico a partir do estudo do externo, material e visível. A expressão na superfície do corpo, mais especificamente do rosto, seria, portanto, a manifestação de elementos experimentados internamente. Assunto de cientificidade, mas também de sociedade e cultura, a fisiognomonia é a "base da civilidade, pois a conduta e os modos do homem estão definidos por uma equivalência entre o homem 'exterior' visível e um homem 'interior' escondido" (COURTINE; HAROCHE, 2007, p. 24). 
PERcursos Linguísticos • Vitória (ES) •v. 10 •n. 25 • 2020 • ISSN: 2236-2592 • Dossiê:

Discursos de resistência e corpos (re)existentes

Reconhecendo a importância do trabalho de Courtine e Haroche para os estudos do rosto ao longo da história, o qual sofreu todo um processo de regramento simbólico, sendo gradativamente conformado a determinados padrões de comportamento socialmente aceitos, gostaríamos de chamar atenção para os rostos que não estão dentro dos padrões, para os rostos silenciados, para os rostos criminosos.

Imagem 1: $\mathrm{O}$ rosto e a caricatura

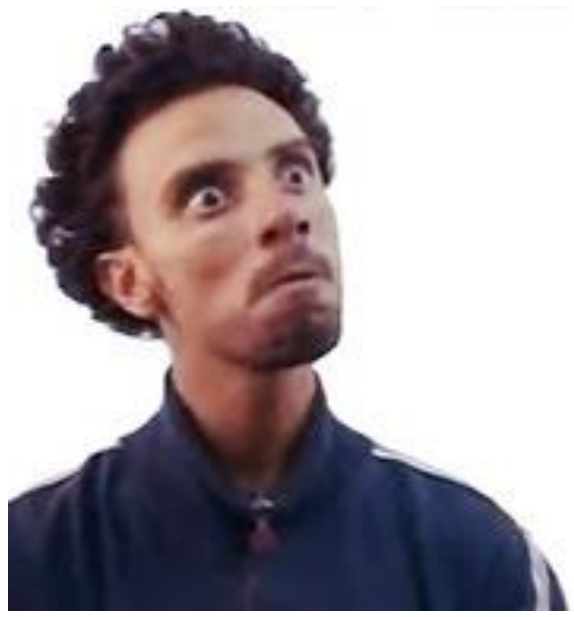

(1)

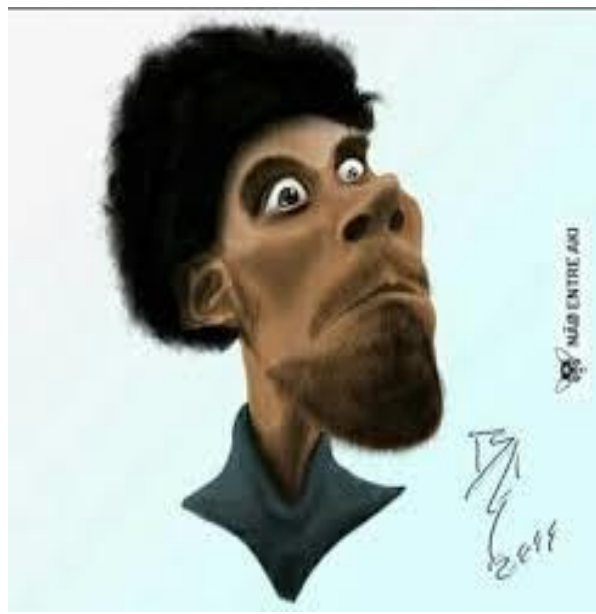

(2)

Fonte: (1) http://bellsmartins.blogspot.com/2011/03/aaaah-morre-diabo.html;

(2) http://www.naoentreaki.com.br/3744686-morre-diabo.htm.

Na imagem (1) temos um print screen ${ }^{3}$ do vídeo Morre diabo - Mata a mãe e xinga imprensa, o qual captura o momento exato que sucede o xingamento "morre diabo". Emílio permanece por pelo menos cinco segundos sustentando essa expressão facial: olhos arregalados, sobrancelhas elevadas, narinas infladas, lábios cerrados. Todos esses elementos se somam à cabeça erguida e à respiração forte. Uma postura ofensiva, na tentativa de amedrontar seus oponentes, de mostrar para eles que não se rende, não "abaixa a cabeça", isto é, não se sente inferior.

A postura altiva e o ar ameaçador externam a resistência da alma, já que o corpo permanece. É dessa forma que esse indivíduo é representado em memes e caricaturas, como mostra a imagem (2). Essa imagem de um sujeito orgulhoso, do qual se esperava rendição, confissão e resiliência, produz comentários como "Adoro esse cara, lendaaario......Queria conhecer ele", justamente por romper com o esperado, por revelar sua rebeldia.

\footnotetext{
${ }^{3} \mathrm{O}$ print screen é um recurso nos teclados de computador e smartphones. Quando a tecla é pressionada, captura em forma de imagem tudo o que está presente na tela.
} 
PERcursos Linguísticos • Vitória (ES) •v. 10 •n. 25 • 2020 • ISSN: 2236-2592 • Dossiê:

Discursos de resistência e corpos (re)existentes

No entanto, de acordo com Milanez (2012), é a nossa maneira de olhar para a representação da imagem do indivíduo que o transforma em sujeito. Isso se revela, por exemplo, em alguns comentários dos internautas que sugerem, pela leitura da expressão facial do indivíduo, perturbação, transtorno e loucura, de maneira tal que a imagem do indivíduo se associa a do diabo: "Homem totalmente perturbado que Deus tenha misericórdia"; "Esse homem é desiquilibrado tem que ser internado em um hospital psiquiátrico"; "Isso não é possessão, nem drogas. Se chama esquizofrenia e é uma doença mt séria"; "Nossa parece um capeta com os olhos a regalando"; "Demônio". Os diferentes olhares produzem, por tanto, diferentes sujeitos. Temos o herói que xinga na frente das câmeras, altivo, valente. Temos o desequilibrado, louco, que precisa de uma intervenção médica. Temos também a encarnação do mal, que transfigura e estampa no rosto os traços de sua perversidade demoníaca.

Por outro lado, agora no campo do discurso, as palavras desse sujeito, outrora sem voz, ainda reverberam na web, ressignificados em diferentes formas e por diferentes vozes: "Se a postagem no espaço digital permite escapar da invisibilidade e das margens, joga a imagem desse corpo na hipervisibilidade da web", assim, "o corpo torna-se prisioneiro do panóptico digital, pode ser olhado, mostrado, esquadrinhado, compartilhado a exaustão" (GREGOLIN, 2015, p. 206). Lembramos que, enquanto acontecimento enunciativo, o discurso desse sujeito possui uma materialidade repetível, podendo sempre ser retomado, jamais definitivo, mas modificável.

Considerando que no vídeo havia mais de dois mil e quinhentos comentários, ao aplicar o princípio de regularidade e dispersão do método arqueológico, proposto a partir dos estudos foucaultianos sobre o enunciado, conseguimos segregar os comentários em quatro categorias:

(a) Reprodução: reúne os enunciados que apenas repetem o discurso do assassino;

(b) Apreciação: agrega os enunciados que revelam algum tipo de apreço dos internautas pelo sujeito infame e/ou seu comportamento, seja aravés do riso ou de manifestações de apoio;

(c) Contradição: reúne os enunciados que revelam por parte dos internautas um conflito moral em que, contraditoriamente, eles apreciam e condenam o assassino;

(d) Lamento: agrega os enunciados em que os usuários demonstram pesar, aversão, antipatia e até mesmo ódio pelo sujeito criminoso ou por outros internautas que riem da situação.

Cada uma dessas categorias abriga conjuntos de enunciados com o mesmo referencial, ou seja, com as mesmas condições de emergência do vídeo, considerando sua natureza de acontecimento (discursivo), tornando-se, assim, elementos dessa trama, seja repetindo, 
PERcursos Linguísticos • Vitória (ES) •v. 10 •n. 25 • 2020 • ISSN: 2236-2592 • Dossiê:

Discursos de resistência e corpos (re)existentes

valorizando, adaptando, modificando, opondo-se ou até mesmo apagando a formulação a qual se referem.

Selecionamos apenas alguns exemplos que representam cada categoria, para não estender a análise de modo a torná-la repetitiva e/ou enfadonha.

a) Reprodução

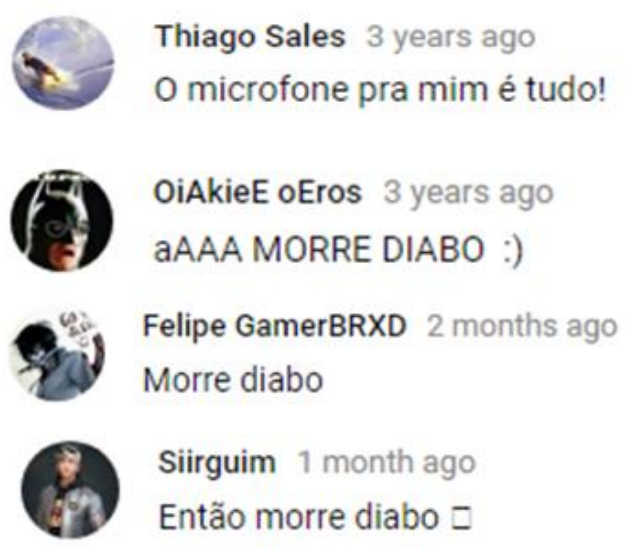

Dentre as categorias apresentadas acima, nos deteremos com mais profundidade nas três últimas, isso porque a primeira (a) Reprodução, que constitui grande parte dos comentários, se resume à repetição do discurso do assassino e, portanto, não apresenta grande variedade de enunciados para análise.

O enunciado que mais se repete é o "morre diabo", o qual se associou à imagem do próprio sujeito, muito mais conhecido pelo meme do que pelo próprio nome. É interessante observamos que a imitação é a própria essência do meme, o que o torna possível. No entanto, importa-nos destacar, nesta categoria, o fato de que a reprodução, pura e simples ou acompanhada de risos, significa uma confirmação desse discurso. No campo do não dito, os sujeitos que repercutem àquilo que foi dito por Emilio Rocha, de certo modo, concordam com ele e, por consequência, com seu comportamento diante das câmeras, tornando o enunciado "morre diabo" um verdadeiro bordão.

b) Apreciação 
PERcursos Linguísticos • Vitória (ES) •v. 10 •n. 25 • 2020 • ISSN: 2236-2592 • Dossiê:

Discursos de resistência e corpos (re)existentes

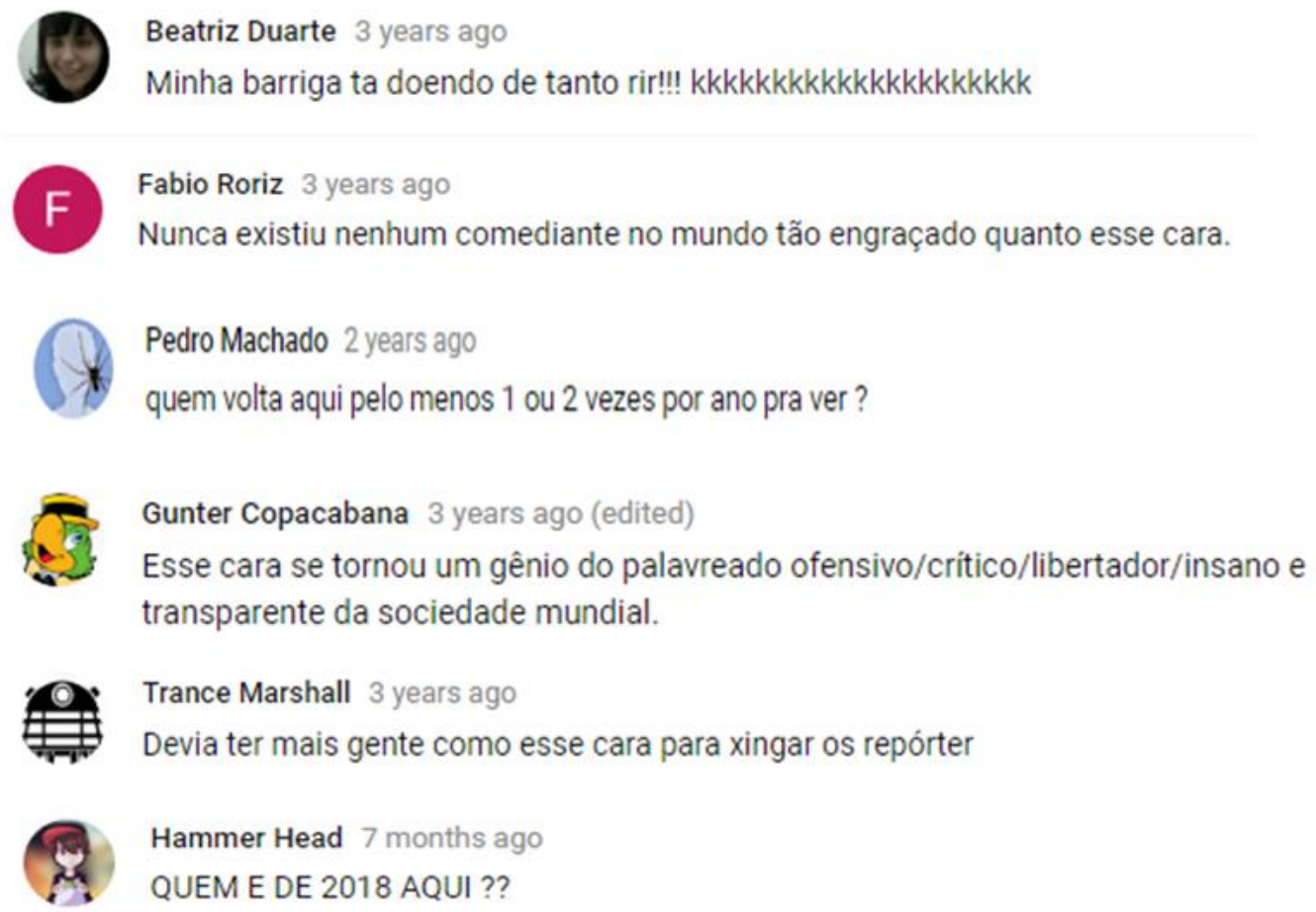

Temos, inicialmente, os enunciados que expressam linguisticamente certa apreciação dos usuários em relação a esse sujeito. Tal apresso pode se dar pela provocação do riso, atribuição de comicidade à situação, revelado no primeiro enunciado pelo somatório da letra "k" (kkkkkkkkkkk), muito comum como representação do riso na linguagem da web, e pela expressão "minha barriga ta doendo de tanto rir!!!”.

No segundo comentário, o usuário afirma que o sujeito protagonista do vídeo é o comediante mais engraçado do mundo, “inigualável”. É possível, através desse enunciado, observarmos uma contradição que começa a tocar o campo da moral. A princípio, temos o valor da piada, que resume esse caso em sua totalidade, ou seja, é consenso que esse sujeito faz rir, isso é confirmado pelo número de likes (32 mil), em comparação com o número de deslikes (1,3 mil), e pela quantidade de comentários que destacam ou interpretam esse acontecimento como cômico. Sendo assim, o sujeito criminoso, que poderia suscitar o ódio e/ou a revolta da população, gera, a partir de um gesto inesperado e explosivo, insensibilidade nos internautas, provocando o riso, produzindo para si a identidade de comediante. Assim, o assassino se torna comediante e vai se subjetivando de outra forma sob o olhar do outro, o que coloca em questão princípios morais basilares em nossa sociedade. Esse monstro do século XXI, que faz rir, atrai a plateia por ser a negação da natureza moral dos homens. 
PERcursos Linguísticos • Vitória (ES) •v. 10 •n. 25 • 2020 • ISSN: 2236-2592 • Dossiê:

Discursos de resistência e corpos (re)existentes

Há ainda enunciados que demonstram certa apreciação pelo assassino: Quem volta aqui pelo menos 1 ou 2 vezes por ano pra ver?; Quem é de 2018 aqui?; esse cara se tornou um gênio do palavreado ofensivo/crítico/libertador/insano e transparente da sociedade mundial. No primeiro enunciado, verificamos a questão da frequência como forma de apreciação do vídeo; no segundo, observamos a atualidade do acontecimento. Temos uma questão ainda mais intrigante nessa categoria, que é a exaltação do comportamento do criminoso. A partir dos princípios de exclusão do sujeito na ordem social de funcionamento do discurso, explanada por Foucault (2014b), o discurso desse sujeito não deveria ser levado em consideração, afinal, são as palavras de um assassino e devem, portanto, ser abominadas. No entanto, como podemos verificar, produz um efeito de aprovação: devia ter mais gente como esse cara para xingar os repórter. $\mathrm{O}$ monstro que faz rir se torna um gênio dos insultos e xingamentos, o teor da comédia passa, portanto, pelo seu discurso transgressor.

Considerando que o nosso interesse recai exatamente sobre as questões sociais suscitadas pela conduta moral dos indivíduos na web, no que diz respeito a crimes e delitos, é importante deixar claro o que entendemos por moral, nesta pesquisa. Segundo Foucault (2017), na Antiguidade a moral filosófica era de ordem estética, tratava-se de elevar a vida a um status, uma escolha pessoal que revelasse o desejo de ter e deixar para os outros a lembrança de uma bela vida, e não de fornecer um modelo de comportamento a todos os indivíduos. Já no Cristianismo, principalmente no que diz respeito ao sexo, a questão da moral tem como objetivo manter e intensificar os princípios da moral romana através do exercício do poder pastoral, e, mais tarde, através de práticas disciplinantes, educativas, médicas ou psicológicas.

Diferentemente do que ocorreu na Antiguidade, a moral passa a ser compreendida como um "conjunto de valores e regras de ação proposta aos indivíduos e aos grupos por intermédio de aparelhos prescritivos diversos, como podem ser a família, as instituições educativas, as Igrejas etc.” (FOUCAULT, 2017, p. 224). Podemos dizer que essas ações não estão dissociadas de uma moral e não são menos diferentes, de uma moral a outra, de um sistema de valores, regras e proibições. Essas regras, de acordo com o autor, podem ser explícitas, na forma de doutrinas, por exemplo, ou difusas, formando um "jogo complexo" com elementos contraditórios, permitindo, assim, certos pontos de fuga.

É esse jogo complexo que parece envolver a série de acontecimentos que compõem o objeto deste artigo, pois tende a considerar na sociedade ocidental certos tipos de condutas e comportamentos, “amorais", passíveis de punição, sendo, portanto, condenáveis, "mal vistos”, 
PERcursos Linguísticos • Vitória (ES) •v. 10 •n. 25 • 2020 • ISSN: 2236-2592 • Dossiê:

Discursos de resistência e corpos (re)existentes

destituídos de honradez. No entanto, no espaço virtual, há movimentos de exaltação de sujeito criminosos e de suas condutas.

c) Contradição

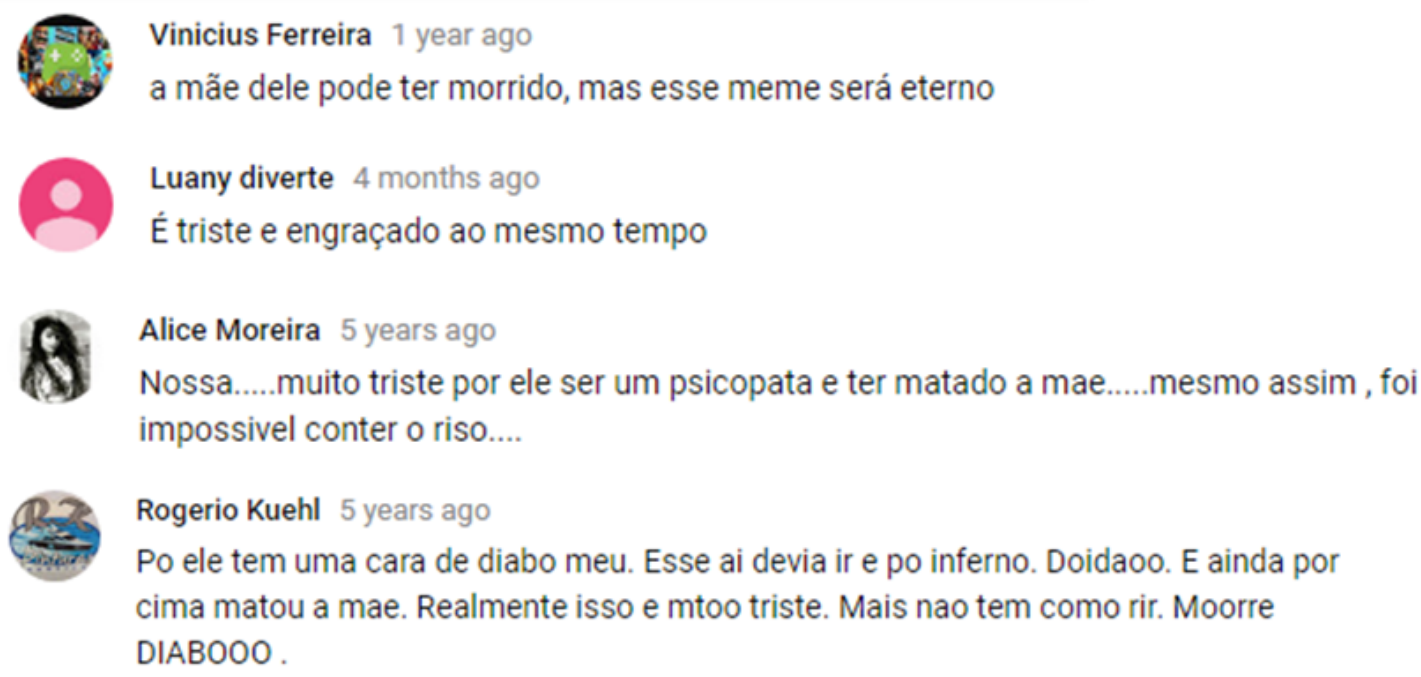

Seguimos a análise com a categoria que intitulamos (c) Contradição. Nesta categoria, a própria estrutura linguística dos enunciados nos dá indícios de ideias contraditórias, como o uso da conjunção adversativa "mas" e do advérbio de modo mesmo: A mãe dele pode ter morrido, mas esse meme será eterno; é triste e engraçado ao mesmo tempo. Nesses comentários temos um riso amargo e inquieto que coloca o sujeito em duas posições diferentes, contraditórias entre si. O fato de a vítima ter um vínculo de parentesco tão próximo com o assassino, o fato de serem mãe e filho, torna o acontecimento ainda mais nefasto.

Há o reconhecimento de que se trata de um crime hediondo, de uma tragédia, ainda assim, mesmo havendo certo lamentem (Nossa.... muito triste por ele ser um psicopata e ter matado a mãe...), os internautas não reagem da maneira "esperada", da maneira "correta", aquela que a ordem moral lhes exige. De acordo com Foucault (1987, p. 11), os enunciados são orientados segundo uma ordem discursiva, porque as leis que fundam uma cultura, ou seja, os códigos aos quais se subordinam sua linguagem, seus esquemas perceptivos, suas trocas, suas técnicas, seus valores, a hierarquia de suas práticas, "fixam, logo de entrada, para cada homem, as ordens empíricas com as quais terá de lidar e nas quais há de se encontrar".

Assim, segundo Foucault (2010), é justo que o criminoso desperte o sentimento de revolta da população, a qual deseja sua punição, principalmente tratando-se de um crime hediondo, cuja prática violenta é de gravidade acentuada, ferindo valores morais legítimos da 
PERcursos Linguísticos • Vitória (ES) •v. 10 •n. 25 • 2020 • ISSN: 2236-2592 • Dossiê:

Discursos de resistência e corpos (re)existentes

sociedade. Entretanto, o que observamos nesse caso é uma reação inversa por parte dos sujeitos. Mesmo admitindo a gravidade do crime, consideram o acontecimento engraçado. Portanto, ainda que reconheçam e condenem o assassinato, confessam que aquela situação, por mais que seja contraditório, faz rir. Isso pode ser observado em enunciados como: tá certo que o assunto em questão é muito sério...; esse aí devia ir e po inferno...; eu sei que é errado... que Deus me perdoe.

Nesta categoria, os valores morais ficam estremecidos mediante ao deleite da comédia, ao espetáculo do sujeito transgressor. Isto coloca em xeque, não apenas os princípios da moralidade da sociedade ocidental (respeito, solidariedade, bondade etc.), como também a problemática da ética (honestidade, justeza de caráter, bom cidadão, etc.), pela qual o indivíduo se transforma e constrói para si seu próprio código moral, possibilitando a emergência de enunciados como: a mãe dele pode ter morrido, mas esse meme será eterno.

d) Repúdio/Lamento



Verificamos também enunciados produzidos por sujeitos cujas reações, diante do acontecimento e, principalmente, em relação ao sujeito criminoso, aproximam-se daquilo que seria o "esperado": a antipatia, o repúdio ou até mesmo o ódio. Esse é o caso dos comentários que compõem a última categoria (d). Ressalte-se, no entanto, que eles fazem parte de uma 
PERcursos Linguísticos • Vitória (ES) •v. 10 •n. 25 • 2020 • ISSN: 2236-2592 • Dossiê:

Discursos de resistência e corpos (re)existentes

minoria quase irrisória, somam apenas $1 \%$ do total de comentários no vídeo, revelando assim sua raridade.

Nos dois primeiros enunciados desta categoria, vemos a manifestação do ódio contra o monstro jurídico por meio da condenação ao inferno e do desejo de uma morte violenta. Esses sujeitos representam o anseio por vingança e a revolta que derivam da cultura do suplício. Porém, como vimos de forma breve no início da seção $O$ corpo monstruoso na obra foucaultiana, as sociedades democráticas possuem modos muito mais "sofisticados" e humanizados de punir, em uma nova economia do poder associado à vigilância, que considera a natureza humana do criminoso e busca compreender os motivos do seu crime, estabelecendo assim uma correspondência direta entre crime e pena, com punição na medida, sem excessos. É nessa perspectiva que se inserem os dois últimos enunciados da categoria (d), que falam dentro do regime de verdade do seu tempo, pois revelam uma preocupação com a gravidade do crime, com a condição social e mental do assassino ("o cara se desequilibrou"), criticando, assim, a postura dos outros usuários que riem da situação.

É interessante observar os jogos de verdade que compõem os enunciados da categoria (d), pois há uma fusão de duas formas de sociedade: a monárquica e a democrática, assim como o suplício e a prisão, a tortura e os direitos humanos.

Nesse sentido, trazemos à tona a questão mais importante a ser levantada na análise desse corpus: há uma contradição entre o politicamente correto, a moral e o cômico, e o entretenimento na web. É nesse espaço que o sujeito criminoso se torna uma celebridade, um meme, um "gênio", um "comediante", ao mesmo tempo em que se evidencia a desumanidade dos seus atos, sua subjetividade monstruosa, provocando o riso e o asco e, com isso, problematizando a moralidade na sociedade contemporânea.

\section{Considerações finais}

Nossa principal preocupação, ao iniciarmos as investigações deste artigo, foi a de analisar como o corpo monstruoso é espetacularizado no espaço heterotópico da web, se tornando um objeto de entretenimento e diversão, especificamente na plataforma de vídeos YouTube.

Observamos que, inseridos nesse espaço, novas identidades eram construídas para esses sujeitos criminosos. Considerando o número massivo de vídeos na categoria de "presos engraçados da internet", privilegiamos a qualidade de raridade dos acontecimentos, optando 
PERcursos Linguísticos • Vitória (ES) •v. 10 •n. 25 • 2020 • ISSN: 2236-2592 • Dossiê:

Discursos de resistência e corpos (re)existentes

por apenas um, mas que se diferenciava de maneira destoante dos demais, o único caso de assassinato, o assassino da própria mãe, Emilio Rocha, o monstro moral.

A partir da construção de saberes sobre o sujeito criminoso, a sociedade teria, assim, o direito de puni-lo, consistindo numa luta desigual, pois de um só lado há todas as forças, todo o poder e todos os direitos. Esse "formidável direito de punir", como afirma Foucault (1987), se dá pelo fato de o delinquente tornar-se um inimigo comum da sociedade. Por isso, reforçamos a ideia de que há uma brecha no dispositivo, pois, no caso analisado, o transgressor e violador da lei não provoca a asco, o repúdio, mas sim o riso, o divertimento e a empatia.

Além disso, verificamos que a mutabilidade da identidade desse sujeito na web produz discussões importantes acerca da moral e da ética dos participantes da cibercultura e, consequentemente, da sociedade como um todo. Por isso, acreditamos que este trabalho propõe, acima de tudo, uma reflexão sobre a liquidez dos alicerces morais que regem a contemporaneidade, o que reforça sua atualidade e importância nos estudos do discurso e das identidades.

\section{Referências}

COURTINE, J. J. Decifrar o corpo: pensar com Foucault. Trad. Francisco Moráes. Petrópolis: Vozes, 2013.

FOUCAULT, M. Vigiar e punir: nascimento da prisão. Tradução de Raquel Ramalhete. Petrópolis: Vozes, 1987.

FOUCAULT, M. Os anormais. São Paulo: Editora Martins Fontes, 2010.

FOUCAULT, M. A Ordem do Discurso. Aula Inaugural no Collège de France, pronunciada em 2 de dezembro de 1970. 24 ed. São Paulo: Edições Loyola, 2014.

FOUCAULT, M. Arqueologia do saber. 8 ed. Rio de Janeiro: Forense Universitária, 2016.

FOUCAULT, M. História da sexualidade I: a vontade de saber. 4 ed. Rio de Janeiro: Paz e Terra, 2017.

GREGOLIN, M. R. Discursos e imagens do corpo: heterotopias da (in)visibilidade na WEB. In: Análise de Discurso em Rede: Cultura e Mídia. Campinas: Pontes Editores, 2015.

GOMES, N. L. Educação e Diversidade Étnicocultural. In: RAMOS, M.; ADÃO, J.; BARROS, G. (coordenadores). Diversidade na Educação: reflexões e experiências. Brasília: Secretaria de Educação Média e Tecnológica/MEC, 2003.

MILANEZ, N. A possessão da subjetividade. In: SANTOS, J. B. C. (org.). Sujeito e subjetividades: discursividades contemporâneas. Uberlândia: EDUFU, 2012. 